\title{
On becoming a skilled migrant - towards habitus transformation through higher education
}

Juliet Thondhlana

\begin{abstract}
Research on the labour market experiences of highly skilled migrants has revealed the crippling employability challenges they face in the UK workplace resulting from the devaluation of their homeland qualifications and experiences. Studies on highly skilled migrants from Zimbabwe have revealed how migrants have to resort to semiskilled and unskilled work for survival. Little is however known about the education and labour market experiences of migrants who come into the UK without degrees and subsequently acquire a UK degree. Drawing on Bourdieu's theory of cultural capital and habitus, this article explores the higher education and labour market experiences of this group as revealed by in-depth interviews with 20 participants. Findings reveal that these participants' habitus is a complex dynamic interaction of diverse (pre)dispositions and strategies which result in them reporting better labour market success than Zimbabwe-degreed migrants. Arguably, their experiences suggest the emergence of a new UK-based habitus for Zimbabwean migrants.
\end{abstract}

Higher education, cultural capital, habitus, Zimbabwean, employability, migrants

\section{Introduction}

The interaction of capital, education and employability in relation to migration has been the subject of much debate in recent years (Erel, 2010; Nash, 2002). Looking at migration from diverse contexts, research has noted the crippling labour market challenges faced by highly 
skilled migrants who in many cases lose their previously accumulated human capital (Chiswick and Miller, 2009) as evidenced by the non-recognition of their qualifications and experiences and labour market insertion failures (Oliver and O’Reilly, 2010). As noted by Madziva, McGrath and Thondhlana (2014) not much research has been carried out on higher education (HE) and labour market experiences of migrants from the commonwealth and especially those from Anglophone Africa. This study, which focuses on Zimbabwean migrants who came to the UK without degrees but have managed to acquire a UK degree, adds to the steady growth of research interest in this population.

Research has documented the labour market challenges faced by Zimbabwean migrants who come to the UK with Zimbabwean degrees and work experience many of whom fail to get jobs in their fields of specialisation due to what is seen as the non-transferability of their qualifications, skills and experiences and who end up seeking employment in the non-skilled and semi-skilled sectors (Madziva, McGrath and Thondhlana, 2014; Mbiba, 2011). Only a few are able to get into skilled jobs, particularly those in the regulated and sought after professions such as engineering and the health sector due to the transferability of their institutionalised cultural capital. Little is however known about the higher education and labour market experiences and outcomes of Zimbabwean migrants who come without a degree but who go on to acquire UK-based degrees.

A brief historical background to the construction of a Zimbabwean education would help illuminate what resources participants' bring with them which facilitate acquisition of a UK degree. Further, a brief background to the UK social, education and economic context participants move into will also help generate an understanding of the institutional structures, which promote or impede their habitus transformation. 
Zimbabwe is a former British colony, which gained its independence in 1980 . In the colonial era, educational policies and practices were designed to limit black (as used in colonial and post-colonial days to refer to natives) people's access to education by creating extreme school-progression bottlenecks for them resulting in only a few of them attending primary school and even fewer proceeding to secondary and higher education. For example, transition rate from primary to secondary was fixed at no more than $12.5 \%$ for students intending to follow an academic education route (which was an imitation of British grammar schools); no more than $37.5 \%$ were channelled toward vocationally oriented secondary education (Dorsey, 1989), while for the remaining $50 \%$ there was no provision to formal education (Zvobgo, 1996). Missionaries had thought that Africans needed a technical/vocational education so that they could raise their standard of living while settlers saw a vocational education for Africans as a way of ensuring that they would occupy low-skilled jobs and not aspire to compete with their European counterparts for so called white collar jobs requiring an academic education (Atkinson, 1972). Vocational education students were consequently stigmatised as being incapable of coping with the complexities of academic work and as a result vocational education was strongly resented by black students and their parents (Dorsey, 1989; Zvobgo, 1996). Of the $12.5 \%$ who pursued an academic education, only $2.5 \%$ would proceed to Advanced Level and eventually only a minute $0.2 \%$ accessed a university education. This system produced an academic doxa representing a belief that only the academic route led to a successful career and was the preserve of the whites and a few privileged blacks. Of the few privileged blacks, girls were discriminated against not only in terms of access to education but they were prepared for domestic work while boys were prepared for work outside the home. The few African girls who made it to higher education were mainly employed as nurses and teachers. (Gordon, 1996).

Paradoxically, these structural restrictions created an even greater demand for education by Africans who began to view it as the only route for their upward mobility, and the few blacks who were allowed access provided inspiration to the majority. Black children were 
therefore socialised to see education, and in particular an academic education, as the only route out of their poverty and a strong desire to attain education to the very highest level was inculcated in them. To this end a university education was highly sought after.

Besides the restrictive educational policies and practices many children failed to attain the appropriate level for access to higher education due to a range of socio-economic disadvantages and challenges. Consequently, only a few blacks at that time managed to get a university education.

While post-independence Zimbabwe recognised the critical need for education to be more accessible to the black majority, as evidenced by the adoption of the principle of education for all, independence of Zimbabwe in 1980 saw a perpetuation of the colonial perception that academic qualifications to university level provided the best possible route to a highly desired 'elitist' (colonial styled) lifestyle (Usap Zimbabwe, 2008). The many stigmatised vocational schools established by the colonial government were phased out and turned into academic schools while technical and vocational subjects were introduced as optional subjects in the secondary school. The direct route to a university education however continued to be restrictive with Advanced Level programmes being quite competitive and most "O" level students "... either returning to small-scale farming, entering the work force or proceeding to a vocational course, a technical school or a nursing or teaching college" (Usap Zimbabwe, 2008, 1). For those not taking the higher education route therefore upward mobility was a slow, painful process often involving starting at the very bottom. This was the plight of participants in this study who failed to make the requisite grades for the Advanced Level route.

Not surprisingly therefore, following independence a new successful middle class mostly consisting of the educated elite emerged that adopted much of the lifestyle of the colonial elite. Thus, education, already well-valued and a major source of unrest under white settler rule, was accorded great value both as a process of cultural capital investment and as key 
to entry into an elite lifestyle (McGregor, 2008). In post-colonial Zimbabwe, and for a long time, possessing a degree virtually guaranteed employment and a salary that also included an accompanying package that might comprise a company car; payment of fees for private schools; paid family holidays and; a subsidised mortgage.

However, the economic downturn of the mid-1990s, and in particular, the interaction of political and economic factors led many Zimbabweans to migrate (Madziva, McGrath and Thondhlana, 2015). Travelling and studying abroad was previously the preserve of so called 'high flyers' with a range of scholarships and grants for study abroad having been highly competitive. This period however offered migration opportunities to all and sundry and an opportunity for desired academic advancement. It should be noted that women, who had borne more of the colonial and post colonial educational restrictions and had long started engaging in cross-border trading to support their families were in many cases the first to migrate and evaluate the opportunities.

Meanwhile around the time participants arrived in the UK the UK Government was continuing with its tradition of emphasising the critical role of higher education credentials in providing access to the UK labour market (Tomlinson, 2008). As stated in the Department for Education and Skills ([DfES] 2003, para 5.5, 59) White Paper:

Graduates and those who have 'sub-degree' qualifications earn, on average, around 50 per cent more than non-graduates ... and, as a group they have enjoyed double the number of job promotions over the past five years.

This highly formalised perspective of human capital where higher education leads to elite jobs and high wages was echoed by the Zimbabwean experience, what appears to be a colonial legacy as evidenced by other work looking at similar colonial contexts such as Ghana (Foster 1965). Similarly, this emphasis led to many in the UK seeking a degree qualification. With a focus on widening participation and lifelong learning further education 
colleges and universities were providing diverse roots into higher education including access programmes, bridging courses and foundation programmes. This period also saw the professionalisation of previously non-degreed careers such as nursing and social work with government providing much needed funding for these in-demand professions.

Consequently, large numbers of graduates with similar educational qualifications were competing for sought after employment. In response to this influx of employment seekers the discourse of graduate employability started shifting from academic credentials to "graduate attributes and skills" such as communication skills, team work skills, social skills (Brown and Hesketh, 2004) as well as personal attributes such as a good personality and the ability to cope in stressful situations. Discipline-specific knowledge was no longer a strong employability determinant except in fields such as medicine and engineering (Tomlinson, 2008). As such there was an increasing need for interviewees to be able to narrativise the skills that made them employable as well as undergo pre-employment tests with degree qualifications only serving basic eligibility (Brown and Hesketh, 2004).

While there was a great demand for high-end jobs, the UK care industry was facing crippling staff shortages of health professionals and social workers as well as unskilled and semi-skilled carers due to structural changes in the industry involving privatisation of care as well as an unwillingness by nationals to take on care jobs (Anderson, 2010). Incidentally, this period coincided with a high influx of migrants to the UK who were prepared to take on any types of available work due to structural employment restrictions resulting from immigration controls, labour market discriminatory practices, non-transferability of skills, and social networks which clustered migrants in certain types of jobs and segments of the labour market usually involving semi-/non-skilled work. In her study of highly skilled Zimbabwean migrants to the UK working in the care industry McGregor (2007) found that while this was considered a demeaning industry particularly for men who would ordinarily not work in care work, for many the industry provided a much-needed stopgap while they sought opportunities to work in their areas 
of expertise or advance themselves through study. This is a common story for participants in this study as will be shown in the findings sections.

Using the notion of cultural capital and in particular Bourdieu's concept of habitus and also drawing insights from related concepts of structure and agency, field and doxa, I explore these migrants' journeys from working in stigmatised non-skilled and semi-skilled industries, to becoming degreed migrants with evidenced good labour market prospects. I argue that they mobilise their existing Zimbabwe-based cultural capital as power to create new forms of capital and habitus so as to increase their chances of labour market success. I begin with a theoretical discussion of the key concepts and then move on to discuss findings from interviews with participants for this study starting with a general profile of participants' educated habitus followed by an exploration of the interaction between their Zimbabwean based habitus and an emerging UK-based habitus or "diasporic habitus" (Gates and Guo, 2014) which enables them to exercise agency in navigating the complex UK HE system and labour market.

\section{Cultural Capital and Habitus}

Bourdieu (1997 [1986]) developed the concept of cultural capital in response to what he saw as the limitedness of an economic view of capital. He conceptualised capital as acquired resources that enable individuals to benefit through the appropriate use of the resources (Williams, 2014). He further identified three key forms of capital including economic capital (material and financial assets), cultural capital (knowledge/experiences acquired over time) and social capital (resources accumulated due to being a member of a particular social group). Of note is that these three forms are convertible into each other (Kelly and Lusis, 2006) for example, availability of economic capital can provide access to further education 
which can lead to the acquisition of cultural capital of an educational qualification and in turn can connect the individual to a network of like educated people.

Social networks can be invaluable in accessing education and finding a job that would generate economic capital for the individual (Ryan, 2011). Bourdieu (1986) viewed cultural capital as the symbolic assets that a person possesses and accordingly characterised it into three forms, that is, the embodied form or habitus ("long-lasting dispositions of the mind and body" (Bourdieu, 1986, 243) such as high self-esteem, resilience, attitude, accent, posture); objectified form (e.g. dress, cultural goods the media, books etc.); and the institutionalised form (e.g. a university degree).

Bourdieu's notion of habitus provides a framework within which the value relating to particular forms of capital are established. He sees habitus as

... systems of durable, transposable dispositions, structured structures predisposed to function as structuring structures, that is as principles which generate and organize practices and representations that can be objectively adapted to their outcomes without presupposing a conscious aiming at ends or an express mastery of the operations necessary in order to attain them (Bourdieu 1990b, 53).

Within this framework is the complex interaction of a number of intersecting elements including structure and agency, field, and doxa, which I discuss below.

Habitus frames and shapes human actions predisposing them to act in particular ways through participation in a particular structured framework called a 'field' or sets of 'fields' (for example, education, labour market). According to Thomson (2017) fields are interlocking 'social worlds' each functioning according to its own set of 'rules of the game'. Each field 
has its own set of beliefs, what Bourdieu calls doxa - an unquestionable orthodoxy (that members of the field have come to view as self-evident and accept as natural, normal and necessary) - which justify the game and are embodied in the habitus thereby framing the kinds of decisions that people make (Thomson, 2017). An example of doxa in the field of education is meritocracy (merit-based progression). Bourdieu however challenged the doxa of meritocracy calling it a myth biased towards particular dispositions and capitals.

Bourdieu $(1984,1979)$ further notes that the environmental and social conditions shared by a particular class of agents create a habitus comprising "schemes of dispositions, perceptions, and appreciations" which in turn orient social practices and lifestyles. The conditions create and establish principles of the group or individual's vision and division of the world which shapes their perceptions and desires (Bourdieu, 1998; Laberge and Kay, 2002). McClelland $(1990,104)$ also argues that habitus "represents the past as well as the present" and is cumulatively influenced by capital and historical feedback on the individual's past successes or failures. Habitus therefore operates subconsciously to influence the way individuals understand, interpret, act and make sense of the world (Thomson, 2017). It is seen as both structured and structuring in the sense that while it is a product of one's position within the social structure it also shapes practice (Bourdieu, 1979). Explaining Bourdieu's conceptualisation of habitus Thomson $(2017,14-15)$ notes that habitus operates subconsciously and predisposes individuals and groups to

- Take particular things for granted

- Believe that particular things are important

- Aspire to particular things,

- Admire and want to possess particular kinds of objects and 
- Want to participate in particular kinds of social, cultural and political events and process

Bourdieu has often been criticised for his emphasis on the class basis of habitus, which suggests the rigidity and deterministic nature of habitus and which appears to rule out the possibility of social mobility and change (Adams, 2006; Reay, 2004). As noted by Edgerton and Roberts (2014, p. 199) this view sees socioeconomically disadvantaged individuals as being “... socialized into dispositions that destine them to think and act in ways that recreate the conditions of their own disadvantage." This perceived conceptual rigidity of habitus is however challenged by other researchers who see it as a misinterpretation of Bourdieu's theory arguing that Bourdieu himself actually acknowledges the possibility of habitus transformation and pointing out that since it is seen as a product of social conditioning it can be endlessly transformed (Bourdieu, 1990a; Hodkinson et al., 2007; Horvat and Davis, 2011; Lee and Kramer, 2013). In some of his later works, Bourdieu himself contends that habitus is "durable but not eternal" as it is continuously reshaped by new environments and experiences (Bourdieu and Wacquant 1992, p. 133) and that it is "not a fate, not a destiny" but as a product of history it can be transformed by historical action (Bourdieu 2005, p. 45). In conceptualising habitus therefore, it appears that Bourdieu recognises both aspects of statics and dynamics and highlights the transformative possibilities of habitus. Wacquant (1998, 221) summarises Bourdieu's view of habitus in this regard as being "the product of structure, producer of practice, and the reproducer of structure".

The above studies have empirically demonstrated the transformative nature of habitus which is argued to result from a change in an individual's social environment requiring that the individual exercise agency and juggle their old habitus and the new habitus acquired through social mobility. This fluidity of habitus enables researchers to understand the interaction of 
humans with changing social circumstances. The statics and dynamics of habitus are seen as falling into 3 categories. First is the situation where an individual's habitus is in sync with their circumstances in which case the habitus stays the same. Then there is the situation where the habitus slightly does not correspond with one's circumstances requiring that the individual adapts to the structure while also slowly modifying their habitus. Third there may be major discrepancies, what Bourdieu calls "times of crises", whereby rapid transformation becomes necessary (Edgerton and Roberts, 2014; Ra, 2011). Others have gone further to view habitus as inventive and creative even in normal conditions (Atkinson, 2010; Baker and Brown, 2007; Hillier and Rooksby, 2005; Maton, 2008). Atkinson (2010) for example sees habitus as underlying the full range of action from less conscious, pre-reflective and routine action to more conscious, intentional and deliberate action, reflecting both agency and structure (also see Nash, 1999). In this regard individuals undergoing the same experiences within a particular environment will have "similar, but not identical" habitus (Edgerton and Roberts, 2014, 202). As Bourdieu notes, “... as no two individual histories are identical so no two individual habituses are identical" (Bourdieu, 1990c, 46).

The current study explores the mediating role of habitus in the relationship between cultural capital, higher education and labour market success following Gaddis $(2013,18)$ who highlights the 'critical mediating factor of habitus'. An examination of participants' Zimbabwean-based educated habitus enables us to understand how they negotiate higher education and employability in terms of their attitudes to both education and work, motivations, strategies, choices and outcomes as they potentially transition into a new UK-based habitus. Habitus is shaped by culture and it then may influence an individual's educational and employment outcomes. Habitus measures such as 'an individual's attitude about their own educational success, and an individual's belief about the value of school' have been used to 
investigate the effects of habitus on cultural capital and educational achievement (Gaddis, 2013, p. 8) and results suggest that cultural capital operates through habitus to influence academic achievement by shaping an individual's view of their ability to succeed. Studies have shown that disadvantaged individuals who are subjected to stereotypes such as that intelligence is fixed and that people with their background are less intelligent, what Steele (1997) calls 'stereotype threat', have developed negative dispositions about their ability to succeed (Owens and Lynch, 2012). On the other hand, a belief in the flexibility of intelligence has been argued to yield more positive results for individuals (Blackwell and Dweck, 2007; Trzesniewski and Dweck, 2007).

In this regard, Steele (op cit), observes that this change involves such individuals perceiving themselves as belonging to a particular domain (accepted and valued); having good prospects within the domain; and possessing the requisite capabilities, motivations, resources, and opportunities to succeed there. Steele further sees a link between stereotype threat to social structure noting the educational access limiting effects of structural factors such as "... historical and ongoing socioeconomic disadvantage, segregating social practices, and restrictive cultural orientations" $(1997,613)$ which manifest in the form of inadequate resources, limited role models and foundational shortcomings and which contribute to hindering them from identifying with academic domains. On this, writing about African migrants to the United States of America, Ojo-Ade (2001) notes the reality of migrants' lived experiences of institutional racism, based on their racial and ethnic backgrounds as people from a continent that some Americans perceive as inferior. As such individuals claim agency in line with their understanding of the rules of constraining structures as well as family expectations, and prevailing economic forces (Eslinger, 2014). These dynamics highlight the link between a change in circumstances and a change in habitus and as this study will show, exercising agency to acquire the cultural capital necessary to facilitate 
transformation. Consequently, how individuals acquire and use a new habitus and the interaction between their old habitus and new habitus is of interest to this study. Transformation is facilitated by the use of what Bourdieu calls strategies which are "products of habitus and of practices adapted to a social field" which help regulate much of human behaviour (Thieme, 2008, p. 61). How individuals use particular strategies to achieve particular goals is part of their habitus. This study adds to the literature that perceives habitus as a flexible entity, particularly in migration and transnational contexts (also see Cornbleth, 2010).

\section{The study}

This paper draws on data collected as part of an ongoing project concerning the lived experiences of Zimbabwean migrants with UK degrees. It is based on in-depth interviews (averaging one hour) conducted with 20 Zimbabwean migrants who came without degrees to the UK but have now attained a UK degree. The sample consisted of 12 women and 8 men, who migrated between 2000 and 2005 as adults ranging in age from 30 to 50 years. Among them were 8 former teachers, 5 secretaries, 2 clerks, 1 travel consultant, 1 tour guide, 1 library assistant and 1 nurse. Following their degree training there were now 5 social workers, 5 nurses, 3 healthcare entrepreneurs, 2 support workers, 1 university lecturer, 1 teacher, 1 ward clerk, 1 factory worker and 1 delivery van man.

The interviewees were selected by snowballing, drawing on the networks of the researcher, who is herself a Zimbabwean graduate migrant with a UK degree. Being an insider researcher (a member of the population being researched) had its advantages. I shared experience with participants in terms of coming from the same country and culture; speaking the same language; and being a migrant with a UK degree. As a migrant, I was acutely aware of some of the sensitivities relating to researching migrants such as having an irregular immigration 
status which may result in an unwillingness to share what may be seen as incriminating information; having gone through traumatic experiences which may lead to mistrust of others, including members of their own communities (Hynes, 2003); embarrassment to talk about their current lowly status; tiredness due to working multiple non/semi skilled jobs; being targeted for research by academics, government and NGOs and the trauma of repeatedly narrating your story without getting any return on time invested. To get round these challenges I had to establish trust and build rapport, drawing on my knowledge of the appropriate cultural behaviour including engaging in small talk (which in most cases is done in the native language); accepting offered refreshments as a symbol of accepting the relationship; allowing the participant to take their time and watching for cultural signals of readiness to discuss more serious issues (this could be asking children to leave the room or silence as a way of allowing me to begin). A small token of appreciation in the form of a voucher or groceries would be appropriate in that culture of gift-exchanging.

It should also be noted that given the snowballing approach, some of these participants may have been acquainted but none of them made any specific reference to the other in their narratives.

It should be noted that the social practices of these participants are much more complex than can be represented in a paper of this nature. A more systematic ethnographic study, which goes beyond observations that can be gleaned from the narratives in these interviews, would enable a more in-depth exploration of habitus in the Bourdieusian perspective. Nevertheless as has been argued (Schneider and Lang, 2014, p. 93) interviews are an important social practice in themselves which provide insights into 'discursive and communicative dispositions'. Thus while these narratives do not provide the whole story, they offer significant glimpses into their social practices relating to education and employability. Also by looking at both individual and 
collective habituses of these subjects as revealed by their individual responses and collective patterns that emerge, one is able to show the interaction between individual and collective attitudes and behaviours and how these influence individual social practices.

All participants in this study gave informed consent prior to their participation in the research, and adequate steps were taken to protect participants' confidentiality. All participants' names have been pseudonymised.

The interviews were recorded and transcribed prior to thematic analysis, which involved reiterative reading of the transcripts (Braun and Clarke, 2006) and identification of statements that could indicate particular dispositions or internalised cultural schemas. To this end an eclectic combination of both the inductive and deductive approaches was adopted (Cresswell, 2009). The process involved beginning with pre-determined themes drawn from the background literature on habitus and transnational migration to see to what extent chunks of interviews matched these and then allowing for new ideas and themes to emerge through reiterative reading and coding. The following themes, which emerged from the analysis will be discussed in the following sections:

- Participants' Zimbabwean habitus: Education as empowerment towards habitus transformation

- Resourceful, opportunistic and pragmatic dispositions

- Social networking

- $\quad$ Starting at the bottom as a means to an end, not an end in itself

- Choosing degree programmes that offer employment versatility and a more secure future

- Using Further Education as access to Higher Education 


\section{Participants' Zimbabwean habitus: Education as empowerment towards habitus transformation}

In this section, I discuss the patterns of education-related habitus that participants bring to the UK as revealed by the findings.

The narratives in this study strongly resonate with the positive orientation towards education, which Bourdieu calls, the 'educated habitus'. Edgerton and Roberts (2010) see the educated habitus as encompassing the desire to be educated as well as to identify and be identified as such. The demand for education to university level noted in the discussion of background is echoed by participants in this study most of whom experienced Zimbabwean education both pre and post independence, for example, Tarirai (former certified nurse turned university senior lecturer with a doctorate) observed:

I think in the system that we had before independence, then after independence, people put more emphasis on education. I don't think if you had clinical or practical skills you were considered valuable enough.

Besides the restrictive educational policies and practices participants studied under they failed to attain the appropriate level for access to higher education due to a range of socio-economic disadvantages and challenges. For example, the girl-child Shingai, former secretary turned nurse, who got pregnant while at school in Zimbabwe had this to say:

After my O Levels, I was pregnant with Tatenda. So then I had to stop everything. So the whole mentality was I needed some cash income, to look after my son. So that's why I ended up having to look for something that was quick, and then that I could 
actually do a job as soon as possible. And having family who didn't have anything, that was just going to be too much of a bother in the whole family.

This added challenge for the girl-child and the impact on their already constrained education is well documented (Human Rights Watch, 2017). In pre- and post-colonial Zimbabwe getting pregnant meant an end to formal education, as schools were not allowed to retain pregnant girls. This highlights the hurdles they had to get through to get a desired education.

For the participants, not taking the higher education route meant that upward mobility was a slow, painful process often involving starting at the very bottom. For example, even after 12 years working for the same organisation Simukai's (former bank clerk turned nurse/social worker) upward mobility was still limited in terms of getting him to the managerial level:

I worked for X bank for 12 years starting in 1988 and I started from being an enquiries clerk, accounts clerk, accounts supervisor, then what we call manager's clerk or log officer then I left X bank in 1997

This reproduction of the colonial academic doxa echoes Grenfell's (2014, p. 116) observation that "Doxa allows the socially arbitrary nature of power relations (e.g. classifications, values, categories etc.) that have produced the doxa to continue being misrecognised, thereby reproducing this same doxa in a self-reinforcing manner."

However, a change in field at the societal level in the form of the economic downturn of the mid-1990s noted above led participants to migrate in search of better livelihoods. In particular it provided them a breakthrough in their wish for opportunities to better themselves 
academically. On this Thomson (2017, p. 22) observes that "In the case of the education field, change might be produced when the political and economic fields to which it is subordinate, respond to shifts in the wider field power - such as those produced through globalisation ..." In this case, due to socio-economic changes in the country of origin where their academic opportunities were limited, migration to a different societal field brings about changes that benefit them academically. As expressed by former teacher turned social worker Shungu,

When I got here I saw that there were a lot of opportunities to better myself academically so with the encouragement of my family as well I decided to go for it.

As noted in the introduction, the socio-economic situation in the UK at the time which promoted and gave access to higher education through widening participation and lifelong learning schemes even to certain categories of migrants (such as refugees and those with settlement) facilitated participants' entry into higher education. As discussed later there were also ways to get funding.

Taking advantage of these developments, Shungu is not satisfied with just a first degree and immediately seeks a higher qualification, a Zimbabwean orientation, as she notes:

I thought I need to do a little bit more studies because I've always wanted to do more. So I thought it was an opportunity for me to do a masters and then look for the job.

This drive is also revealed in other narratives. Former secretary and cross-border trader turned social worker, Revai, saw the UK as an 'enabling' environment which offered her the opportunities that Zimbabwe had not given her to fulfil her dream to pursue higher education, 
The drive, I can say, is that being a Zimbabwean from home I've been wanting to be a professional person. Zimbabwe didn't actually allow me to do the things I wanted to do, career wise, so when I came here, I saw that opportunities are available for you to actually do whatever you want.

The link between higher education, employability and social mobility was at the fore for her

When I started there were quite a lot of opportunities really because I could see probably 10,15 jobs in a day coming through and I'll be thinking, "Oh, when I qualify things will be fine,"

Bourdieu notes that individuals are able to exercise agency and interrogate their dispositions and doxic assumptions and do things they are not accustomed to. This secretary cross-border trader has started to dream much bigger. Obviously, the employability challenges in the UK labour market at that time, as already discussed, would not have been evident for her at that time. However, unlike in her Zimbabwean context here she could see possibilities of realising her aspirations.

In another case, although Tarirai (former nurse turned university senior lecturer with a doctorate and award winning innovator) was doing well as a certified nurse having risen to the level of junior ward manager, driven by the educated habitus he felt that this was not good enough because of the lack of a degree particularly in an environment that presented opportunities for higher education.

I became the junior ward manager. But I wasn't actually very satisfied, because I did not have a degree. 
Asked why a degree was so important for him, he said

That's again, back in Zimbabwe, where education was always pushed to children, or to students. So that was in my mind, that when I'm managing these colleagues, I should have a degree, and a Masters is actually a bonus.

However, for some of these migrants the transition to higher education has not been a straightforward process as their institutional capital in the form of their high school qualifications is not always transferable to fulfil the prerequisite for UK higher education institutions. To this end Kelly and Lusis (2006, p. 835) observe that “... between one habitus and another, capital of various types may be evaluated quite differently, and this is a difference that migrants experience acutely. ... and particular assets may have a symbolic worth in one context and not in another". For example, Kundai, former secretary and crossboarder trader turned social worker, says of her experience:

My qualifications are of much value in Zimbabwe, but when you come here what the British people do is they want to value their own things. I remember when I was looking for a place to do social work at X University, I went with all my certificates because I did Cambridge O Levels. They couldn't recognise the certificates though they are Cambridge certificates.

Despite these structural hurdles presented by the UK context, Kundai is able to draw from her resourceful or opportunistic disposition produced through Zimbabwe's harsh economic field where she made the decision to embark on cross-border trading to fend for her family.

In their pursuit of a UK higher education and driven by their shared resourceful and 
pragmatic dispositions, these migrants are able to realise that in order to increase their labour market chances they need to quickly understand and internalise UK education values. For example, through their exposure to the UK education system, their educated habitus is transformed to seeing higher education as being more than just acquiring a qualification but developing critical cognitive dispositions such as analytical, problem solving and communicative skills alongside their degree qualifications so as to meet the requirements of the UK labour market. As Zivai, former teacher turned nurse/health visitor observes:

It's the skills. It's not the qualification, the employers are not looking for the qualification that's why in the health visiting they do skills based interviews because they want to know whether they will be able to communicate with families Analytical skills are also needed everywhere you go. For the job I'm doing right now you need your brains to be thinking that way.

Therefore while their Zimbabwean educated habitus propels them to seek higher education, the UK educated habitus produces practices, perceptions and orientations that make them competitive on the UK labour market. In the next section I consider products of habitus which make habitus transformation possible for these participants.

\section{Resourceful, opportunistic and pragmatic dispositions}

The ability to adopt and adapt the outcomes of past opportunities and constrains created by the colonial, post-colonial systems and diasporic situations is critical for these migrants to compete in the global economy and it requires that they exercise agency to enable them to negotiate higher education and employability (in terms of, for example, financial resourcing, degree and work choices). This exercise of agency is driven by a range of dispositional 
properties and an understanding of rules of the game of the UK HE and labour market fields and related strategies (seen by Bourdieu as 'products of habitus and of practices adapted to a social field' (Thieme 2008, p. 61)) that enable them to deal with adaptations and transformations. In the following sections I consider these accompanying dispositions and related strategies showing how they help shape their habitus transformations. As noted in the literature, how individuals use particular strategies to achieve their goals is part of their habitus (Thieme, 2008). I start by looking at social networking.

\section{Social networking}

An aspect of their Zimbabwean based habitus which they mobilise for negotiating the UK HE and labour market fields is the use of social networks. Thondhlana et al $(2016,7)$ have noted that "... in-group networking is typical of the Zimbabwean collectivist culture whereby members largely rely on social ties to attain career mobility...” Participants' narratives suggest that they were part of a diverse network of family, friends, and workmates. Bourdieu (1986, p. 249) underscores the value of social networks "... showing that the volume of the resources accessible to an individual depends on the size and quality of associations that the individual can effectively mobilize". Similarities of trajectories of these participants suggest a common use of social networks, confirmed in their narratives, in decision making about their degree programme choices as Shingai notes

There was a friend who was doing Human Services who influenced me to take it. I didn't even know what it was. He said 'I'm doing a degree in Human Services and this degree is good because when you finish there are so many avenues you can follow". So I joined him in the same program. 
Similarly, Zivai found encouragement from a work colleague

There was this guy from Zimbabwe who was doing supply teaching as well, so every time we would communicate and say, and then he'd say, 'I've seen this course and I think you should do this course.

The extent to which social networks positively influence these participants is however a matter for debate. On the one hand it can be argued that they have provided them with useful information about what fields guarantee them employment. On the other hand the networks may be seen as channelling some of these participants into specific labour market spaces of nursing and social work and hindering them from trying out other possible avenues. In a similar study under development involving younger migrants who came as children or were born in the UK it was noted that they were using professional networks which channelled them to more diverse job opportunities than their parents' limiting networks. Age was therefore a significant factor in participants' strategies. Nevertheless, the ability of these participants to use social networks as a resource is a part of a Zimbabwean habitus that enables some of them to transform to a new transnational or UK-based habitus.

\section{Starting at the bottom as a means to an end, not an end in itself}

As noted before, these participants' tough Zimbabwean education and labour market experiences have trained them to adopt a pragmatic orientation to challenging situations so as to benefit even from their circumstances no matter how precarious. This disposition makes reproduction of the educated habitus in the UK context possible. In this regard they needed to understand the prevailing labour market dynamics in the UK as outlined in the introduction terms of a high competition for white collar jobs and immigration restrictions on migrant 
employment in the backdrop of a "British jobs for British workers" discourse. As noted by McGregor (2007) the care industry offered much needed financial relief for individuals and families whether as a stepping-stone to other work or as a career opportunity in itself for some. Pragmatism seems to have been a reasonable approach to take.

For example, Shingai attempts to make sense of her demeaning care assistant job by reasoning that,

... because after doing care work, you actually see 'Oh okay, fine, nursing will probably be okay.' I don't mind being a carer, but being a qualified nurse would be better. When you become a nurse there are a few added responsibilities. Because nursing is just mainly, it's care, you're caring for a patient who is not able to care for themselves.

In this example, Shingai is able to see connections between health care work and nursing seeing nursing as the higher level of care work to work towards thus seeing her denigrated job as a worthwhile step towards something bigger. Similarly, former certified teacher turned degree-d Social Worker Shungu, whose aspiration is to eventually set up her own business in care services sees her demeaning work as a way of laying the groundwork to realising her dreams.

Whilst I'm working in support work, I'm also doing my research on how they run their services because that's my goal as well, to get my own place and set up support for people. 
This orientation provides them with the flexibility they need to navigate their way into HE as a pathway to employability. Many times they find that care work provides the experience they need to get into social and health care degree fields.

Choosing degree programmes that offer employment versatility and a more secure future.

As another pragmatic move, participants in this study drew from their networks and experiences (including for example, their demeaning jobs as stepping stones) to decide which careers provided security, flexibility and a range of work choices. These include careers that guarantee work availability, multi-strand degrees, joint degree programmes and multiple degrees and certificates. Findings from this study have revealed that most participants chose to study nursing and social work professions for a range of reasons. One opportunistic reason is that these are fields currently believed to guarantee employment due to the noted staff shortages in that field.

The rumour which was going around was "People get employed when they are nurses or social workers" so I sat down with my wife and said "Look, maybe I need to retrain" (Kurai, former agriculture teacher turned nurse)

All participants who attained degrees in these fields have managed to find work while those who chose other areas have struggled due to the competitiveness in those fields. For example, former professional tour guide Nhamo who has completed both Bachelors' and Masters' degrees in Ecology in the UK had not been able to find a professional job. 
Since I came into this country, I've worked in factories. Even after gaining my degree qualifications I've not been able to find other work.

Also former teacher Simbai who studied a degree in Childhood Studies still had to find work in education and she continued to do support work. Besides the competitiveness of some of these fields, institutional racism and discriminatory practices were sometimes quoted as causal factors. For example, former secretary and bank clerk Chemai who dared to study a degree in Community Justice and then got stuck in support work had this to say

I wanted to do a degree that would enable me to become a Probation Officer. I was told that they were no longer taking foreigners even with a British passport.

Her case is however particularly interesting in that after a long time in semi-skilled work she decided to identify those skills she had acquired from her Zimbabwean and UK education and work experiences which are transferable to other types of work and easily got an administration job in a hospital. Of getting this job she says

I realised that I could combine my various skills and experiences working as a secretary and clerk in Zimbabwe and studying my degree to find a fit with admin

This is significant because it also suggests the emergence of a new UK-based habitus for this group and possibly the wider Zimbabwean diaspora in the UK whereby education is more than just gaining a qualification but gaining transferable skills which enhance labour market access (Madziva et al, 2014). 
Nursing and social work professions are also preferred because of the availability of government funding as expressed in the following narrative:

At that particular time I could have gone and done an accountancy course. But who is going to pay for my fees? Then I got a place to do my nurse training because that was the easiest thing that I could do without paying fees.

(Shingai)

It is however ironic that these professions which in Zimbabwe were viewed as routes for 'the failed' and were also feminised have become routes for getting a desired degree and therefore means of habitus transformation for both men and women. Timeously, these occupations have only become recently degreed in the UK and this suggests an opportune process of professionalisation for these migrants.

Another resourceful move they make is to choose programmes that offer multiple routes as a way of guaranteeing employability. For example, Kurai chose to do a degree in human services which offers strands in social work, education, public health and human resources.

This Human Services degree programme focusses on public health management, managing all the education. We did a module in education; a module in human resources, a module in health, all the services that are managed by government; that's why they call it Human Services.

Equally calculating Simukai, former bank clerk turned nurse/social worker, makes some strategic decisions about his career move 
Whilst I was thinking of doing nursing I realised that ... there was actually a programme whereby I could do social work and also at the same time do nursing.

\section{Using Further Education as access to Higher Education}

Participants noted that Zimbabwean qualifications do not always provide access to UK HE. Further Education (FE) however offers them an opportunity although in Zimbabwe it carries a stigma as the route for 'failed' and 'problem' students (Zinyama, 2005). While in the UK it is equally denigrated by its association with occupational trades leading to low skilled jobs and low pay (Gleeson, 2015), it appears to have a higher exchange rate for these participants having offered them access to higher education in the UK. Participants' narratives show this benefit.

\footnotetext{
When I was looking for a place to do social work at X University, I went with all my certificates. They couldn't recognise the certificates though they are Cambridge certificates. When I was researching, I realised that I could do a course called Access to Social Work, which is equivalent to A Level just to get me into this degree that I ended up doing. (Gonai, former secretary turned social worker)
}

Overall the findings of this study have revealed a number of dispositions and related strategies that appear to propel participants in their pursuit of higher education and a necessary transformation in habitus.

\section{Conclusion}


This paper set out to explore the processes of social mobility adopted by a group of Zimbabweans who came to the UK without degrees and the resources that they were able to mobilise to transition into employable highly skilled migrants with UK degrees. This group contrasts with highly skilled migrants who come with Zimbabwean highly valued degree qualifications and work experiences who have been found to struggle to transition to the UK labour market following the devaluation of their institutionalised capital (Thondhlana, et al (2016). This makes this group an interesting population to study in order to better understand the evolvement of a Zimbabwean diaspora habitus.

Bourdieu's notion of habitus was found useful in helping to unpack and understand the adopted processes and resources. The findings reveal that for these participants the habitus is a complex dynamic interaction of diverse (pre)dispositions involving the past, and present, the individual and group and structure and agency. A combination of dispositions including resourcefulness, opportunistic and pragmatic orientations, traits developed over years of a challenging Zimbabwean existence, appear to have resulted in greater labour market successes for them. Driven by their Zimbabwean habitus, participants have had to exercise agency and strategically engage in and manipulate the rules of their home country and their social situation in the UK field, playing a 'game' of going to university and learning rules of the game in the process. In so doing, they have adopted a range of carefully crafted opportunistic and pragmatic moves including taking advice from social networks, doing bridging access courses to university, deciding which programmes to take and at what point of their immigration process in order to gain economic capital to cover the cost of their studies.

While the participants do transform from being semi-skilled to skilled migrants with context relevant degrees that give them access and successful insertion into the UK labour market, this 
does not seem to translate into complete transformation of their old dispositions, attitudes and strategies. We have therefore seen how they exercise agency in constructing new forms of 'migration-specific cultural capital' (Erel 2010, p. 643) carefully realigning the embodied and institutional states of their cultural capital from Zimbabwe and the UK. This way they are able to build on their Zimbabwean habitus pragmatically choosing careers in fields that guarantee work for non-degreed Zimbabweans in Zimbabwe and which to their advantage also offer higher education and more employment prospects in the UK context and with greater currency than in Zimbabwe. While this cautiousness is understood especially in the face of the 'failures' of most participants who have dared to venture far afield, one participant's ability to find work in a different environment using the skills transferability strategy commonly employed in the UK environment shows the emergence of a new habitus for these migrants to reinvent themselves as marketable products through higher education. We have also seen how certain Zimbabwean dispositions resulting from their socialisation as well as years of navigating Zimbabwe's precarious education and employment terrain for this group have provided them with the resilience, high aspirations, hardworking, a willingness to take small steps (e.g. carework-access course to HE), starting from the bottom which enable them to maximise on the opportunities the UK context presents them.

Still much more needs to be known about this category of Zimbabwean migrants. For example, one area that was briefly mentioned in the narratives and which warrants a more in-depth exploration in future research than is possible in this study is an orientation towards entrepreneurship. 
Studies (Luebker, 2008) have noted how since independence, Zimbabwe has seen a significant growth in the informal sector with many small business enterprises having been established. Not surprisingly therefore some of the participants noted a desire to go into entrepreneurship. Further, methodological limitations have already been noted with respect to use of subjective accounts and how these do not provide the full story of the migrants' experiences. Longitudinal studies which include a focus on their work experiences would provide richer accounts.

\section{References}

Adams, M. 2006. "Hybridising habitus and reflexivity." Sociology 40 (3): 511-528

Anderson, B. 2010. "Migration, immigration controls and the fashioning of precarious workers." Work, employment and society, 24 (2): 300-317.

Atkinson, N. J. 1972. Teaching Rhodesians: A History of Educational Policy in Rhodesia. London: Longman

Atkinson, W. 2010. Class, individualisation and late modernity: In search of the reflexive worker. Basingstoke, UK. Palgrave Macmillan.

Baker, S., and B. Brown. 2007. "Images of execelence: constructions of institutional prestige and reflections in the university choice process." British Journal of Sociology of Education 28 (3): 377-391.

Bibby, D., A. Cerqua, M. Gould, D. Thomson, and P. Urwin. 2015. Further Education: Social Mobility, Skills and Second Chances. London: University of Westminster, Westminster Business School. Retrieved March 6, 2016 https://www.westminster.ac.uk/news/2015/cuts-in-further-education-hit-disadvantagedthe-hardest-report-finds)

Blackwell, L. S., K. H. Trzesniewski, and C. S. Dweck. (2007). "Implicit theories of 
intelligence predict achievement across an adolescent transition: A longitudinal study and an intervention." Child Development 78: 246-263

Bonner, A., \& Tolhurst, G. (2002). Insider-outsider perspectives of participant observation. Nurse Researcher, 9(4), 7-19.Bourdieu, P. 1977b. Outline of a theory of practice. Cambridge: Cambridge University Press

Bourdieu, P. 1979. Outline of a theory of practice. London: Cambridge University Press.

Bourdieu, P. 1984. Distinction. London: Routledge and Kegan Paul.

Bourdieu, P. 1986. “The forms of capital.” Pp. 241-259 in Handbook of theory and research for the sociology of education, edited by J. G. Richardson. New York: Greenwood Press.

Bourdieu, P. 1990a. In Other Words: Essays Towards a Reflexive Sociology. Cambridge: Polity Press.

Bourdieu, P. 1990c. Sociology in question. Cambridge: Polity Press.

Bourdieu, P. 1997. "The forms of capital." 46-58 in Education: Culture, Economy, Society Halsey, edited by A. H. Halsey, H. Lauder, P. Brown and A. S. Wells. Oxford: Oxford University Press.

Bourdieu, P. 1998 [1994]. Practical reason: On the theory of action. Cambridge: Polity Press Bourdieu, P. 2005. "Habitus.” 43-49 in Habitus : A sense of place, edited by J. Hillier and E. Rooksby. Aldershot, Hants, England, Burlington, VT: Ashgate.

Bourdieu, P, and L. J. D.Wacquant. 1992. An Invitation to Reflexive Sociology. Chicago: Chicago University Press

Braun, V. and Clarke, V. 2006. Using thematic analysis in psychology. Qualitative research in psychology, 3 (2): 77-101.

Brown, P, and A. Hesketh, A. 2004. The mismanagement of talent. Oxford: University Press. Cornbleth, C. 2010. "Institutional Habitus as the de facto Diversity Curriculum of Teacher 
Education.” Anthropology and Education Quarterly 41: 280-297.

Creswell 2009. Research design: qualitative, quantitative, and mixed methods approaches. Sage Publications.

Dorsey, B. J.1989. "Educational development and reform in Zimbabwe.” Comparative Education Review 33 (1): 40-58.

Dweck, C. 2007. Mindset: The new psychology of success. New York: Ballantine Books Edgerton, J. D., and L. W. Roberts. 2014. "Cultural capital or habitus? Bourdieu and beyond in the explanation of enduring educational inequality." Theory and Research in Education 1477878514530231.

Erel, U. 2010. "Migrating Cultural Capital: Bourdieu in Migration Studies.” Sociology 44 (4): $642-660$.

Eslinger, J.C. 2014. "Navigating between a rock and a hard place: Lessons from an urban school teacher. Education and Urban Society 46 (2): 209-233.

Foster, P. 1965a. Education and social change in Ghana. Chicago: University of Chicago Press.

Gaddis, S. M. 2013. "The influence of habitus in the relationship between cultural capital and academic achievement." Social Science Research 42 (1): 1-13.

Gates, P. and Guo, X. 2014. "How British-Chinese parents support their children: a view from the regions." Educational Review 66 (2): 168-191.

Grenfell, M.J. 2014. Pierre Bourdieu: key concepts. Routledge.

Gleeson, C. P. 2016. "Residential heat pump installations: the role of vocational education and training." Building Research \& Information 44 (4): 394-406.

Gordon, R. 1996. "Legislation and educational policy in Zimbabwe: The state and the reproduction of patriarchy." Gender and Education, 8 (2): 215-230.

Hillier, J., and E. Rooksby. 2005. Habitus: A sense of place. Aldershot: Ashgate. 
Hodkinson, P., Biesta, G. and James, D., 2007. Understanding learning cultures. Educational Review 59 (4): 415-427.

Horvat, E. M., and J. E. Davis. 2011. "Schools as sites for transformation: Exploring the contribution of habitus." Youth \& Society 43 (1): 142-170.

Hynes, T., 2003. New issues in refugee research. The issue of 'trust'or 'mistrust'in research with refugees: choices, caveats and considerations for researchers. Geneva: Evaluation and Policy Analysis Unit, The United Nations Refugee Agency.

Kelly, P., and T. Lusis. 2006. "Migration and the transnational habitus: evidence from Canada and the Philippines." Environment and Planning A 38 (5): 831-847.

Labaree, R.V. (2002) The Risk of 'Going Observationalist': negotiating the hidden dilemmas of being an insider participant observer, Qualitative Research, 2(1), 97-122. http://dx.doi.org/10.1177/1468794102002001641

Laberge, S., and J. Kay. 2002. "Pierre Bourdieu's sociocultural theory and sport practice." Theory, sport and society 239-266.

Lee, E. M., and R. Kramer. 2013. "Out with the old, in with the new? Habitus and social mobility at selective colleges." Sociology of Education 86 (1): 18-35.

Luebker, M. 2008. "Employment, unemployment and informality in Zimbabwe: Concepts and data for coherent policy-making."

Maton, K. 2008. "Habitus." Pierre Bourdieu: key concepts 49-65.

Madziva, R., S. McGrath, and J. Thondhlana. 2014. “Communicating employability: The role of communicative competence for Zimbabwean highly skilled migrants in the UK." Journal of International Migration and Integration 1-18.

Mbiba, B. 2011. "Beyond abject spaces: enterprising Zimbabwean diaspora in Britain." African Diaspora 4 (1): 50-75.

McGrath, S., R. Madziva, and J. Thondhlana. 2015. "Rethinking the employability of 
international graduate migrants: Reflections on the experiences of Zimbabweans with degrees from England." Journal of Further and Higher Education 1-22.

McClelland, K. 1990. "Culmative disadvantage among the highly ambitious." Sociology of Education 63, 102-121.

McGregor, J. 2007. "'Joining the BBC (British Bottom Cleaners)': Zimbabwean migrants and the UK care industry." Journal of Ethnic and Migration Studies 33 (5): 801-824.

McGregor, J. 2008. "Abject spaces, transnational calculations: Zimbabweans in Britain navigating work, class and the law." Transactions of the Institute of British Geographers 33(4): 466-482.

Nash, R. 1999. "Bourdieu,'habitus', and educational research: Is it all worth the candle?" British journal of sociology of education 20 (2): 175-187.

Nash, R. (2002) The educated habitus, progress at school and real knowledge, Interchange, $33,27-48$.

Owens, J., and S. M. Lynch. 2012. "Black and Hispanic immigrants' resilience against negative-ability racial stereotypes at selective colleges and universities in the United States." Sociology of education 85 (4): 303-325.

Ra, E. 2011. Understanding the role of economic, cultural, and social capital and habitus in student college Choice: An investigation of student, family, and school contexts. Diss. The University of Michigan, 2011.

Reay, D. 2004. “"It's All Becoming a Habitus”: Beyond the Habitual Use of Pierre Bourdieu's Concept of Habitus in Educational Research', British Journal of Sociology of Education 25 (4): 431-444.

Ryan L. 2011. “Migrants' social networks and weak ties: accessing resources and constructing relationships post-migration." The Sociological Review 59 (4): 707-24.

Schneider, J., and C. Lang. 2014. "Social mobility, habitus and identity formation in the 
Turkish-German second generation." New Diversities 16 (1): 89-105.

Steele, C. M. 1997. "A threat in the air: How stereotypes shape intellectual identity and performance.” American Psychologist 52, 613-629.

Steele, C. M., and J. Arouson. 1995. "Stereotype threat and the intellectual test performance of African Americans.” Journal of Personality and Social Psychology. 69, 797-811.

Stroessner, S. and C. Good. 2011. "Stereotype threat: An overview." Retrieved on, 9 (2), p.2013.

Thieme, S. 2008. "Sustaining Livelihoods in Multi-local Settings: Possible Theoretical Linkages Between Transnational Migration and Livelihood Studies." Mobilities 3 (1): $51-71$.

Thondhlana, J., R. Madziva, and S. McGrath. 2016. "Negotiating employability: migrant capitals and networking strategies for Zimbabwean highly skilled migrants in the UK." The Sociological Review. DOI: 10.1111/1467-954X.12373

Tibasima, M. 2017. Africa: Make girls' access to education a reality. Dakar: Human Rights Watch.

Tomlinson, M. 2008. “'The degree is not enough': students' perceptions of the role of higher education credentials for graduate work and employability." British journal of sociology of education 29 (1): 49-61.

Usap Zimbabwe. 2008. Education in Zimbabwe. Usapglobal. Retrieved May, 122016. (http://www.usapglobal.org/zimbabwe/education.htm)

Verter, B. 2003. "Spiritual capital: Theorizing religion with Bourdieu against Bourdieu." Sociological Theory 21 (2): 150-174.

Wacquant, L. 1998. "Pierre bourdieu." Key sociological thinkers. Macmillan Education UK. 98: 215-229.

Williams, K. 2014. Jamaican Middle-Class Immigrants in Toronto: Habitus, Capitals and 
Inclusion. $\mathrm{PhD}$ thesis. Queen's University, Kingston, Ontario, Canada.

Zvobgo, C. J. M. 1996. A history of Christian missions in Zimbabwe, 1890-1939. Gweru, Zimbabwe: Mambo Press. 